УДК 947.7(092)

DOI: 10.24919/2519-058x.6.123898

Василь ДЕРЕВІНСЬКИЙ, orcid.org/0000-0001-5967-2328 професор, доктор історичних наук, професор кафедри політичних наук Київського начіонального університету

будівництва і архітектури (Україна, Kиїв)vasyldr@ukr.net

\title{
УЧАСТЬ В. ЧОРНОВОЛА У ПРОТИДІЇ РОСІЙСЬКІЙ АГРЕСИВНІЙ ПОЛІТИЦІ ЩОДО УКРАЇНИ У 1990-х рр.
}

У статті вивчається участь В. Чорновола у формуванні украйнсько-російських відносин 1990-х рр. Розглядаються агресивні дії російської сторони проти української державності, зокрема посягання на територіальну цілісність, військовий флот. Аналізуються дії В. Чорновола щьодо протидіі російському втручанню. У висновках зазначено, щэо В. Чорновіл був прихильником добросусідських украйнсько-російських відносин, основаних на принципах рівноправності і взаємовигоди. Зважаючи на російські агресивні дії щодо України, В. Чорновіл відстоював ідею посилення основ національної безпеки.

Ключові слова: В. Чорновіл, Україна, Росія, агресія, територіальні претензї.

Vasyl'DEREVINSKYI, PhD hab. (History), Professor of Department of Political Science of Kyiv National University of Construction and Architecture, (Ukraine,Kyiv),vasyldr@ukr.net

\section{VYACH. CHORNOVIL'S PARTICIPATION IN THE COUNTERACTION TO THE RUSSIAN AGGRESSIVE POLICY DIRECTED AGAINST UKRAINE IN THE 1990s.}

To explore the historical development of the national community, it is important to study the ideas and activities of prominent personalities who have influenced the course of events. The prominent Ukrainian public-political and state-creative figure Vyacheslav Chornovil belongs to such figures. His influence on the Ukrainian historical process is noticeable during the 1960-1990s. He took an active part in the state and political life of the 1990s as a people's deputy and chairman of the People's Movement of Ukraine. He directly participated in the Ukrainian-Russian interstate relations, influenced the formation of the policy towards Russia. Therefore, the main task of this article is to analyze the participation of $V$. Chornovil in the tense process of formation of modern Ukrainian-Russian relations.

He established close relations with many Russian opposition figures during the struggle against Soviet totalitarianism and during while in concentration camps on the territory of Russia. In August 1991, V. Chornovil, together with the Russian democratic forces, coordinated joint actions at a dangerous time for Ukrainian and Russian democracy, just when in the Soviet Union had an attempt at a coup d'etat.

After the restoration of Ukraine's independence, relations with the part of Russian leaders at $V$. Chornovil have changed dramatically. They negatively reacted to Ukrainian independence. Such a position can be explained by the fear of losing Ukraine, which for the former metropolis was a significant reservoir of material goods and human potential. Those who cherished imperial ambitions, realized that without Ukraine, Russia would not be able to revive a full-fledged empire like the former empire.

$V$. Chornovil was not surprised at the new attitude to the processes in Ukraine, because he had the experience of long-term dialogue with Russian oppositionists. He tried to convey to Russian leaders an understanding that Ukrainian and Russian peoples will benefit from fruitful Ukrainian-Russian dialogue, understanding and cooperation. Chornovil V. demanded from the Ukrainian authorities during talks with the Russian side to stubbornly defend national interests, no to trade in sovereignty. Criticized both Leonid Kravchuk and Leonid Kuchma for failing to first no take control of the Black Sea Fleet, and subsequently agree with Russia the deadline for the withdrawal from the Ukrainian territory of the Russian Navy. 
The conclusions note that $V$. Chornovil was a supporter of good-neighborly Ukrainian-Russian relations, based on the principles of equality and mutual benefit. In view of Russia's aggressive actions against Ukraine, $V$. Chornovil advocated the idea of strengthening the foundations of national security.

Key words: V. Chornovil, Ukraine, Russia, aggression, territorial claims.

\author{
Василь ДЕРЕВІНСЬКИЙ, \\ профессор, доктор исторических наук, \\ профессор кафедры политических наук \\ Киевского начионального университета \\ строительства и архитектуры, \\ (Украина, Киев), vasyldr@ukr.net
}

\title{
УЧАСТИЕ В. ЧОРНОВИЛА В ПРОТИВОДЕЙСТВИИ РОССИЙСКОЙ АГРЕССИВ- НОЙ ПОЛИТИКЕ НАПРАВЛЕННОЙ ПРОТИВ УКРАИНЫ В 1990-х ГГ.
}

В статье изучаетсяучастие В. Чорновола в формировании украинской-российскихотношений 1990-хг2. Рассматриваются агрессивные действия российской стороны против украинской государственности, в частности посягательство на территориальную иелостность, военный флот. Анализируются действия В. Чорновола, направленные на противодействие российскому вмешательству. В выводах отмечается, что В. Чорновил был сторонником добрососедских украинской-российских отношений, основанных на принципах равноправия и взаимовыгоды. Учитывая российские агрессивные действия в отночении Украины, В. Чорновил отстаивал идею усиления основ национальной безопасности.

Ключевые слова: В. Чорновил, Украина, Россия, агрессия, территориальные претензии.

Постановка проблеми. Для грунтовного осмислення історичного поступу національної спільноти важливо вивчати ідеї та діяльність відомих особистостей, які впливали на перебіг подій. До таких постатей належить визначний український громадсько-політичний і державотворчий діяч В'ячеслав Чорновіл. Його вплив на український історичний процес простежувався протягом 1960 - 1990-х рр. Він брав активну участь в державному і політичному житті 1990-х pp. як народний депутат та голова найбільшої української національно-демократичної партії - Народного Руху України. Безпосередньо був учасником українсько-російських міждержавних відносин, впливав на формування політики щодо Росії.

Аналіз досліджень. За останній час історіографія про постать В. Чорновола примножилася кількісному і якісному вимірі. 3'явилося коло дослідників, котрі спеціалізуються на вивчені питань, пов'язаних з діяльністю В. Чорновола, очолюваного ним Руху тощо. Надруковано праці, в яких розглядається його життєвий шлях (Деревінський, 2016) або розкриваються певні аспекти діяльності (Ведмідь, 2013). Дослідники В. Чорновола та його доби отримали серйозну джерельну базу завдяки виходу десятитомника праць В. Чорновола (Чорновіл 2002 - 2016). У працях, присвячених життю В. Чорновола або історії НРУ, висвітлюються окремі моменти його участі у проваджені українсько-російських відносин (Гончарук, 1997). Системне і скрупульозне вивчення цього питання залишається справою нових наукових студій.

Мета статті. Зважаючи на актуальність вивчення участі В. Чорновола у формуванні українсько-російських відносин 1990-х рр., підготовлена ця стаття. У ній йдеться про співпрацю В. Чорновола з російськими демократичними діячами під час спроби державного перевороту в Радянському Союзі та про їхню ідейну трансформацію після проголошення відновлення незалежності України. Розглядаються агресивні дії російської урядовців проти української державності, зокрема посягання на територіальну цілісність, військовий флот. Аналізуються дії В. Чорновола щодо протидії російському втручанню. Метою статті є осмислити і розкрити участь В. Чорновола у напруженому процесі становлення новітніх українсько-російських відносин.

Виклад основного матеріалу. В. Чорновіл цікавився історією українсько-російських відносин ще зі студентських років. Під час боротьби з радянським тоталітаризмом, перебуванні в ув’язнені та заслані на території Росії в нього склалися тісні відносини з багатьма російськими 
опозиційними діячами. Узгоджував і координував В. Чорновіл з російськими демократичними силами спільні дії в небезпечний для української і російської демократії час спроби державного перевороту в СРСР в серпні 1991 р. Фактично він щопівгодини телефонував до Московської міської ради, де діяв кореспондентський пункт об'єднання «Демократична Росія», а через півгодини - до Верховної Ради Російської Радянської Федеративної Соціалістичної Республіки (РСФСР), зв'язувався з іншими містами Росії. Спілкувався у телефонному режимі з першим заступником Голови Верховної Ради РСФСР Русланом Хасбулатвим, головою Ленінградської міської ради Анатолієм Собчаком, держсекретарем Генадієм Бурбулісом, працівниками апарату Президента Росії Бориса Єльцина. Надіслав Б. Сльцину та А. Собчаку заяви про підтримку й одержав відповіді з подякою. Завдяки взаємопідтримці і допомозі вдалося не допустити реваншу комуністичних реакціонерів. Зі знищенням радянської тоталітарної системи, відновленням незалежності України між В. Чорноволом і деякими російськими демократичними діячами відбулося «охолодження» стосунків. Як сказав класик: російська демократія закінчується там, де починається українське питання. Тому, мабуть, В. Чорновола не здивували, хоча й неприємно вразили, заяви людей з оточення лідера російських демократів - Президента Росії Б. Сльцина та його щодо територіальних претензій до України чи про самовільне перевезення ядерної зброї 3 території України в Росію. В оприлюдненій 27 серпня 1991 р. заяві Б. Сльцина, підготовленій його прес-секретарем Павлом Вощановим, йшлося: «Російська Федерація не ставить під сумнів конституційне право кожної держави і народу на самовизначення. Однак існує проблема кордонів, неврегульованість якої можлива і допустима тільки при наявності закріплених відповідним договором союзницьких відносин. У разі їх припинення РРФСР залишає за собою право поставити питання про перегляд кордонів» (Вощанов, 2003). 3 подібними посилами щодо національного питання серед російської еліти В. Чорновіл зіштовхнувся у ході спілкування 3 іiї представниками в попередні роки (Чорновіл, 1991а). Частина російських опозиційних діячів 1960 - 1980-х рр. виявляли несприйняття ідеї про самовизначення українського народу. Серед тих, хто в 1991 р. не зійшов зі шляху демократії в українському питані на манівці, В. Чорновіл називав відому російську опозиціонерку Олену Боннер, співголову руху «Демократичної Росії» Юрія Афанасьєва та деяких інших (Чорновіл, 2011а: 370).

Після проголошення відновлення незалежності України до Києва терміново прибула російська делегація, серед членів якої були відомі демократичні діячі, як Анатолій Собчак, Сергій Станкевич. 3 українського боку участь у переговорах брали депутати Верховної Ради, з-поміж яких був і В. Чорновіл. У ході переговорів проявилось прагнення посланців нової демократичної Росії упустити з українсько-російського комюніке пункт про територіальну недоторканість держав. Хоча в підписаному в листопаді 1990 р. договорі між УРСР і РСФСР йшлося про недоторканість кордонів у рамках СРСР. Завдячуючи наполегливості української сторони вдалося внести цей пункт у комюніке та не допустити фіксації у ньому ідеї модифікації СРСР.

При розмові з російськими демократами В. Чорновіл запитав їх прямо: «Ви розумієте, що ви наробили»? Маючи на увазі недавні заяви Б. Єльцина та його оточення, які призвели до нагнітання в Україні міжнаціонального тертя та антиросійських настроїв, які не спостерігалися до того в українському суспільстві. Анатолію Собчаку відверто сказав: ««Ви нас зрадили своїми заявами про територіальні претензії, ви застромили ніж у спину української демократії» (Чорновіл, 2012: 180). Натомість В. Чорноволу довелося почути від А. Собчака сакраментальну фразу, яка розставила крапки над «і»: «Я наполовину українець, але краще це було б не так!». Нове віяння у ставленні російських демократів до своїх недавніх українських побратимів В. Чорновіл назвав своєрідним «панським демократичним імперіалізмом».

Попри нові акценти в діалозі між українськими і російськими демократами В. Чорновіл позитивно сприймав підписання українсько-російського комюніке в серпні 1991 р., вважаючи його майданчиком для майбутніх переговорів в усіх напрямах. Висловив оптимізм щодо розгортання українсько-російських відносин, зазначивши, що «будемо з Росією дружити» (Чорновіл, 1991b).

Зважаючи на дедалі наростаючі імперіалістичні зазіхання російського керівництва і політикуму на український суверенітет, висловлювання В. Чорновола щодо Росії ставали катего- 
ричнішими. Такі його висловлювання і дії із захисту української державності є зрозумілими і необхідними, зважаючи на масштаби російської агресивної політики щодо України.

Уже під час підготовки в Україні до проведення референдуму (1991) щодо підтримки громадянами незалежності з Росії направлялися «десанти» агітаторів, завданням яких було поширювати антиукраїнські шовіністичні гасла, підігрівати місцевий сепаратизм. Зокрема, лунали ідеї створення Донецько-Криворізької республіки, приєднання Криму до Росії або утворення окремої кримської держави. 3 різноманітними акціями, спрямованими проти української державності, iї суверенітету, територіальної цілісності, до України приїжджали відомі російської політики.

Демонстративно показуючи зневагу до української державності, російські державні посадовці, включно з прем’єр-міністрами чи депутатами парламенту, заздалегідь не узгоджували 3 українською стороною свої візити до України.

Не минуло й року після відновлення незалежності України як з'явилися офіційні територіальні претензії російських органів влади. У липні 1992 р. Верховна Рада Російської Федерації заявила претензії на Крим, а в липні 1993 р., порушивши всі чинні міжнародні норми, депутати російського парламенту ухвалили рішення про надання українському місту Севастополь статусу міста Російської Федерації.

У жовтні 1996 р. Державна дума РФ ухвалила закон про припинення поділу Чорноморського флоту між Україною і Росією, в якому прозвучали територіальні претензії до України. Після цього депутати Держдуми ініціювали новий розгляд питання про «російський статус» Севастополя. У результаті 24 жовтня 1996 р. Державна дума Російської Федерації прийняла звернення до Верховної Ради України, в якому російські депутати, не вдовольнившись претензіями на Чорноморський флот і Севастополь, заявили про історичне право Росії на всю Автономну Республіку Крим.

Антиукраїнські ухвали російських парламентарів викликали обурення в українському суспільстві. В стінах Верховної Ради України з ініціативи очолюваної В. Чорноволом фракції Народного Руху України та депутатської групи «Реформи» запропонували внести зміни до Конституції України, які б виключали можливість перебування іноземних військ не території України, та прийняти рішення про негайне виведення російського флоту за межі Української держави (Заява, 1996). Законодавчі ініціативи українських депутатів про термінове виведення підпорядкованих Росії частин Чорноморського флоту мали певний вплив, і антиукраїнські виступи в Держдумі на деякий час припинилися, а з порядку денного зняли питання щодо Севастополя.

В. Чорновіл категорично не сприймав політики висунення територіальних претензій сусіднім державам як методу досягнення своїх національних інтересів. Він чітко усвідомлював, що подібне веде до збурення і дестабілізації міжнародної ситуації, підриває принципи світоустрою (Інтерв'ю, 1991). В. Чорновіл апріорі відкидав ідею висунення Україною територіальних претензій сусіднім країнам, водночас зазначаючи, що Українська держава не допустить, щоб хтось ставив ці домагання перед нею. Як депутат і лідер однієї із найбільших українських політичних партій, він шукав способів протидії агресивним заявам і діям російського державного керівництва, що суперечили підписаним угодам та наданим гарантіям.

Східний сусід не приховував свого небажання налагоджувати рівноправні відносини з Україною. Поліпшення україно-російських відносин не відбувалося, за лакованим фасадом дружби проглядала гібридна війна Росії проти України. Російська сторона продовжувала не визнавати морського кордону з Україною, відмовлялася від розподілу континентального шельфу в Керченській протоці та в Азовському морі, ігнорувала права України на Чорноморський флот, який базувався на українській території.

Напереконання В. Чорновола, українськомукерівництвунаприкінці 1991-напочатку 1992-гор. необхідно було швидко взяти Чорноморський флот у своє підпорядкування, коли більшість його особового складу була готова перейти служити Україні (Чорновіл, 1997).

Російське керівництво провадило агресивну політику підпорядкування собі Чорноморського флоту, незважаючи на будь-які домовленості й угоди. Фактично підконтрольне Росії, а формально - головкому СНД командування Чорноморського флоту розпочало пересліду- 
вання офіцерів, які присягнули на вірність Україні. Найбільш цінне майно флоту й сучасна зброя, включно з новими кораблями, вивозилися на територію Російської Федерації. Актом безпосередньої агресії став штурм із подальшим силовим захопленням морськими піхотинцями військової комендатури Севастополя, особовий склад якої присягнув Україні. Згодом відбувся організований масовий перехід кораблів Чорноморського флоту під російські прапори без узгодження такого кроку з українською стороною. Останні агресивні дії Росії В. Чорновіл назвав логічним завершенням політики, що розпочалася 3 проголошення територіальної автономії Криму й продовжилася підписанням невигідних угод з Росією в Ялті й Дагомисі, а також порівняв цю політику з «умиротворенням» Німеччини перед Другою світовою війною. Він вкотре наголошував про те, що українському керівництву наприкінці 1991-го - на початку 1992 р. необхідно було швидко взяти Чорноморський флот у своє підпорядкування, коли більшість його особового складу була готова перейти служити Україні (Чорновіл, 1997).

Заразом він нагадав про свої неодноразові заклики переглянути українсько-російські угоди щодо Чорноморського флоту, які грубо порушувалися російською стороною. Наголосив на нагальності відмовитися від цих очевидно невигідних Україні домовленостей. Критикував ухвалене рішення про спільне російсько-українське командування флотом на п’ятирічний термін. Уважав питання Чорноморського флоту, як і поєднане з ним питання російського втручання 3 приводу Криму і Севастополя, національною проблемою, приводом для шантажу України 3 боку Росії. А тому вимагав домагатися на переговорах з Росією рішення про негайний і остаточний розподіл флоту між двома державами та фіксування в угодах тимчасового перебування російського флоту на українській території. Після підписання чергових домовленостей щодо Чорноморського флоту в Сочі в 1995 р. В. Чорновіл на засіданні Президії Верховної Ради України порушив питання щодо ухвалення закону про статус іноземних військ на території України. «Ніяких «особливих стосунків», - наголосив він, - ніякого «стратегічного партнерства» (узагалі невідомо, що то таке) - ставлення тільки як до іноземної бази, зумовленої в часі, за відповідну платню» (Чорновіл, 1995).

Різко негативно відреагував В. Чорновіл на підписання у травні 1997 р. між Леонідом Кучмою і Борисом Єльциним угод щодо Чорноморського флоту. Він потрактував їх такими, що підписані з порушенням Конституції України, «не відповідають національним інтересам України, погіршують ситуацію в Криму й Севастополі, закладають механізм безкінечної присутності російських військ на території України, стають перешкодою на шляху інтеграції України в європейські структури» (Чорновіл, 1997).

За гучними фразами про взаємовигідність угод фактично приховувалася узаконена тривала російська присутність на всьому узбережжі Криму, що й надалі дозволяло дестабілізувати ситуацію в Україні, робити їі, по суті, заручницею Росії.

Найбільше заперечень у В. Чорновола викликали положення угоди про 20-річний термін оренди Російською Федерацією на території України баз, акваторій та інфраструктур флоту колишнього СРСР з перспективою продовженням оренди на наступні п'ять років. Українське керівництво в ході переговорів відмовилося від заявленого спочатку п'яти-семирічного строку оренди бази. В. Чорновіл вважав такий тривалий термін оренди бази (та ще й без узгодженого графіку виводу іноземних військ) нічим іншим, як узаконенням окупації частини української національної території (Чорновіл, 2011b). Його найсильніше занепокоїла передача в користування російському флоту більшої частини акваторії та інфраструктури військово-морської бази Севастополя й Севастопольської бухти. Крім того, без належних узгоджень і розмежувань Росія присвоїла інші значні українські території за межами бази. Не було проведено й інвентаризації майна та територій.

В'ячеслав Чорновіл назвав сміхотворною плату Росії за оренду бази, визначену на рівні 97,75 мільйона доларів США. Встановлену ціну він охарактеризував як наочне свідчення напівколоніального статусу України. Адже якби ведення переговорів було іншим, то й ціна оренди відповідала б світовим розцінкам. За відповідними розрахунками Міністерства фінансів України, орендна плата Росії мала б складати щороку більше 4 мільярдів доларів США. 
Існувала ціла низка інших неприємних для України аспектів, закладених у договорі про Чорноморський флот. 3 огляду на такий зміст угоди, що безпосередньо загрожував національній безпеці й обороноздатності України, В. Чорновіл заявив, що фракція НРУ не голосуватиме за ратифікацію цього договору у Верховній Раді України. Підстав для такої позиції у нього було більш ніж достатньо. Події початку 2014 р. в Україні засвідчили обгрунтованість його висловлювань. Пророчими виявилися такі слова В. Чорновола: «Питання, що розглядається, має надзвичайно важливе значення як для зовнішньої безпеки нашої держави, насамперед іï територіальної цілісності, так і для безпеки внутрішньої. У кінцевому рахунку від того, як воно буде вирішено, залежить майбутній розвиток України як незалежної держави, а може, і сама доля нашої незалежності» (Чорновіл, 2011b).

Висновки. Таким чином, у російських демократичних лідерів несприйняття незалежного від Росії поступу України проявилося одразу ж після проголошення відновлення Української держави. До таких недружніх випадів проти України їх, мабуть, підштовхував страх втратити Україну, яка для колишньої метрополії була значним резервуаром матеріальних благ і людського потенціалу. Ті, хто плекав імперські амбіції, розуміли, що без України Росія не зможе відродити повноцінну імперією на зразок колишньої, бо разом із іншим втрачала розтиражовані міфи про свою велич і тисячолітні традиції тощо.

Різка зміна акцентів щодо неї у риториці російського політичних діячів для В. Чорновола не виявилася несподіваною, адже в нього був досвід тривалого спілкування з російськими опозиціонерами. Тому він, залишаючись на незмінних позиціях щодо налагодження добросусідських українсько-російських відносин, закликав російський політикум утримуватись від недружніх випадів проти України. Він намагався донести до російських лідерів розуміння того, що від плідного українсько-російського діалогу, порозуміння і співпраці виграють як український, так і російський народи. Усвідомлюючи, що для російської верхівки і значною мірою для суспільства потрібний певний час для того, щоб позбутися імперського ставлення до своїх сусідів, В. Чорновіл наголошував на потребі зміцнення різних ділянок національної безпеки України. Вимагав від українських владних команд під час переговорів з російською стороною непохитно відстоювати національні інтереси, не торгувати суверенітетом. Критикував як Леоніда Кравчука, так і Леоніда Кучму за нездатність спочатку взяти під свій контроль Чорноморський флот, а згодом узгодити з Росією кінцевий термін виведення з української території російського військового флоту. Збройна агресія Росії на територію України, анексія Криму, окупація східноукраїнських територій стала трагічним унаочненням слушності прогнозів В. Чорновола, на жаль, українські владоможці до них не прислухались.

\section{СПИСОК ВИКОРИСТАНИХ ДЖЕРЕЛ І ЛІТЕРАТУРИ}

Ведмідь, 2013 - Ведмідь Л. Постать В’ячеслава Чорновола в національній пам’яті // Гілея. 2013. № 1. C. 761-765.

Вощанов, 2003 - Вощанов П. Как я объявлял войну Украине // Новая газета. 2003. 23 октября.

Гончарук, 1997 - Гончарук Г. Народний Рух України: історія. Одеса, 1997. 378 с.

Деревінський, 2016 - Деревінський В. В’ячеслав Чорновіл: дух, що тіло рве до бою. Харків, 2016. $496 \mathrm{c}$.

Заява, 1996 - Заява фракції Народного Руху України та депутатської групи «Реформи» // Голос України. 1996. 29 жовтня.

Інтерв'ю, 1991 - Інтерв'ю бере народ // Високий замок. 1991. 12 листопада.

Чорновіл, 1991а - Чорновіл В. Будуймо державу пліч-о-пліч // За вільну Україну. 1991. 28 серпня.

Чорновіл, 1991b - Чорновіл В. Комюніке - наша перемога // За вільну Україну. 1991. 30 серпня.

Чорновіл, 1997 - Чорновіл В. Відверто - про найважливіше // Час-Тіте. 1997. 1-18 червня.

Чорновіл, 1995 - Чорновіл В. Рік рішучих заяв і не дуже рішучих дій // Свобода. 1995. 18 липня.

Чорновіл, 2002-2016 - Чорновіл В. Твори: в 10-ти т. Київ, 2002-2016.

Чорновіл, 2011a - Чорновіл В. Твори: в 10-ти т. Київ, 2011. Т. 7. 1079 с.

Чорновіл, 2011b - Чорновіл В. Твори: в 10-ти т. Київ, 2011. Т. 10. 1003 с.

Чорновіл, 2012 - Чорновіл В. Твори: в 10-ти т. Київ, 2012. Т. 8. 1082 с. 


\section{REFERENCES}

Vedmid, 2013 - Vedmid L. Postat Viacheslava Chornovola v natsionalbii pamiati [The figure of Vyacheslav Chornovil in national memory]. Gileia. № 1. Pp. 761-765. [in Ukraine].

Voshchanov, 2003 - Voshchanov P. Kak ya obiavil voinu Ukraine [How I declared war on Ukraine]. Novaia gazeta. 2003. 23 oktiabria. [in Russian].

Goncharuk, 1997 - Goncharuk G. Narodnyi Rukh Ukraiy: istoriia [People's Movement of Ukraine: History]. Odesa, 1997. 378 s. [in Ukraine].

Derevinskyi, 2016 - Derevinskyi V. Viacheslava Chornovil: dukh, shcho tilo rve do boiu [Vyacheslav Chornovil: the spirit that tear the body to the battle]. Kharkiv, 2016. 496 s. [in Ukraine].

Zaiava, 1996 - Zaiava fraktsii Narodnogo Rukhu Ukrainy ta depytatskoi grypy «Reformy» [Statement of the faction of the People's Rukh of Ukraine and the deputy group «Reforms»]. Golos Ukrainy. 1996. 29 zhovtnia. [in Ukraine].

Interviu. 1991 - Interviu bere narod [Interview takes people]. Vysokyi zamok. 1991. 12 lystopada. [in Ukraine].

Chornovil, 1991a - Chornovil V. Buduimo derzhavu plich-o-plich [Let's build the state side by side]. Za vilnu Ukrainu. 1991. 28 serpnia. [in Ukraine].

Chornovil, 1991b - Chornovil V. Komiunike - nasha peremoga [Communique is our victory]. Za vilnu Ukrainu. 1991. 30 serpnia. [in Ukraine].

Chornovil, 1997 - Chornovil V. Vidverto - pro naivazhlyvishe [Outright - about the most important]. ChasTime. 1997. 1-18 chervnia. [in Ukraine].

Chornovil, 1995 - Chornovil V. Rik rishuchykh zaiav I ne duzhe rishuchykh dii [A year of decisive statements and not very decisive action]. Svoboda. 1995. 18 lypnia. [in Ukraine].

Chornovil, 2002-2016 - Chornovil V. Tvory: v 10-ty t. [Works: in 10 t.]. Kyiv, 2002 - 2016. [in Ukraine].

Chornovil, 2011a - Chornovil V. Tvory: v 10-ty t. [Works: in 10 t.]. Kyiv, 2011. 1079 s. [in Ukraine].

Chornovil, 2011b - Chornovil V. Tvory: v 10-ty t. [Works: in 10 t.]. Kyiv, 2011. T. 10. 1003 s. [in Ukraine].

Chornovil, 2012 - Chornovil V. Tvory: v 10-ty t. [Works: in 10 t.]. Kyiv, 2012. T. 8. 1082 s. [in Ukraine].

Стаття надійшла до редакиії 17.02.2018 p. 